\title{
The effect of ownership structure, board of commissioners' effectiveness and audit committee effectiveness on firm value: An empirical study of listed companies in the Indonesia stock exchange 2014
}

\author{
F. Yosi \& R. Yuniasih \\ Department of Accounting, Faculty of Economics and Business, Universitas Indonesia, Depok, Indonesia
}

\begin{abstract}
The objective of this research is to examine the effect of the ownership structure, board of commissioners and audit committee effectiveness on the value of a firm. Institutional and managerial ownerships were used to measure ownership structure. The board of commissioners' effectiveness was measured by its independence, activity, size and competence, based on Hermawan (2009). Audit committee effectiveness was measured by the educational background of its members and the number of meetings it held. The value of the firm was measured using Tobin's Q. Involving 412 companies listed in the Indonesia Stock Exchange (BEI) in 2014, this empirical study with multiple regression shows that institutional and managerial ownerships, board of commissioners' effectiveness and audit committee effectiveness have no significant effect on the value of a firm.
\end{abstract}

\section{INTRODUCTION}

A company is an organisation founded by a group of people working to achieve the common goal of gaining profits and increasing prosperity for its shareholders. In the long term, the objective is to increase the value of the company (Sudana, 2001). In the process of maximising value, sometimes a conflict of interests between the agent and the employer (principal), often called an agency problem, may arise. The management are more concerned with their own interests, which are not in accordance with the company's goal of increasing the shareholders' value. Without good corporate governance in place, this would lead to increased costs, which later on would affect the value of the company.

In companies with weak corporate governance, the actions of managers tend to be selfish (Darmawati, 2004). Managers, as the agents of the shareholders, are entrusted with the company. However, without good corporate governance, shareholders may lose confidence. Therefore, it is important to protect the interests of the shareholders from management expropriation. A corporate governance mechanism can be in the form of institutional ownership, because the presence of an institution will empower the monitoring of the management performance so that the management would be more cautious when making decisions.

Another corporate governance mechanism that can be put in place to discourage the selfish actions of managers is providing managers with ownership of the company. Management ownership will encourage the management to enhance shareholder value. The results of a study conducted by Jensen and Meckling (1976) prove that the ownership of shares by the management has a positive effect on a firm's value. The greater the proportion of management ownership, the more likely it is for the management to try harder for the benefit of the shareholders, who are none other than themselves.

Public companies in Indonesia are also subject to the appointment of independent directors who come from outside the issuer or public company. The number of independent directors shall be at least $30 \%$ of the total members of the board of commissioners. The higher the 
percentage of independent board members, the better the oversight and co-ordination of the company; this will increase the value of the company. Other characteristics of the board of commissioners' effectiveness in monitoring the company's performance are the activity, size and competence of the board of commissioners.

It is also mandatory for public companies to have an audit committee to help the board of commissioners to exercise their duty of oversight, especially related to financial information and reports. The existence of the audit committee will contribute to the quality of financial reporting, which can enhance a firm's value. The purpose of establishing an audit committee is to assist the commissioners or board of supervisors with ensuring the effectiveness of the implementation of the tasks of the external auditor and the internal auditor. The characteristics of the audit committee that can help the monitoring process are the educational background of its members and the number of meetings.

This research analysed factors hypothesised to be affecting a firm's value, namely (i) institutional ownership, (ii) managerial ownership, (iii) effectiveness of the board of commissioners, and (iv) effectiveness of the audit committee.

\section{LITERATURE REVIEW}

Jensen and Meckling (1976) describe an agency relationship as a contract in which one or more principal assign another person (the agent) to perform some service for them by delegating decision-making authority to the agent. According to Jensen and Meckling (1976), the ownership structure is believed to have the ability to influence the running of the company, which in turn can affect the performance of the company. Institutional ownership is a resource that can be used to promote optimal control of management performance in order to anticipate managerial actions that do not conform to shareholders' wishes. Institutional ownership will encourage supervision, which will ensure the increased wealth of shareholders. The concentration of institutional ownership increases public confidence in the company, which increases trading volume and stock price, and this will increase the firm's value (Tarjo, 2008). Amba (2014) states that institutional owners are more concerned about the return on their investment, so their contribution to the effective corporate governance of the company can enhance financial performance. Abukosim et al. (2014) state that the higher the level of institutional ownership in the company, the greater the interest and control, which can improve the function for overseeing the management; this will boost the performance and value of the company.

\section{H1: Institutional ownership significantly affects a firm's value}

Managerial stock ownership means that managers have a stake in the company, or that the managers are also corporate shareholders (Rustiarini, 2006). Share ownership by the management will lead to better control over the policies taken by the management itself. Fauzi and Locke (2012) found positive relations between managerial ownership and a firm's value. This is based on the agency theory that high managerial ownership can decrease the agency costs, which later on increases the firm's performance and its value. Other studies by Debby et al. (2014) and Abukosim et al. (2014) found that managerial ownership does not have a significant relationship to the firm's value; this happens because the management are under the control of shareholders, so that even though they have shares in the company, they do not try to maximise the shareholders' wealth.

\section{H2: Management ownership significantly affects a firm's value}

Corporate governance mechanisms are geared up to ensure and oversee the governance system at work in an organisation (Sudiyatno \& Puspitasari, 2010). The monitoring mechanisms in corporate governance are divided into two groups, internal and external mechanisms (Lastanti, 2004). An internal mechanism is a way to control the company by using the structure and internal processes, such as the general meeting of shareholders, the composition of the board of directors and audit committee, and meetings with the board of directors. 
Previous studies concluded that the larger the size of the board, the greater the monitoring of the company and the higher the availability of independent commissioners who can mitigate management wrongdoings, which will certainly increase the firm's value (Barnhart \& Rosenstein, 1998; Fauzi \& Locke, 2012). Other studies by Debby et al. (2014) found no significant relationship between the proportion of independent commissioners and the firm's value. However, an active board of commissioners reflects actual and updated control over the management, which enhances the possibility of achieving better results and increasing the firm's value.

H3: Board of commissioners' effectiveness significantly affects a firm's value

McMullen (1996) found that investors, analysts and regulators consider that an audit committee provides a positive contribution to the quality of financial statements. This implies that the existence of an audit committee positively and significantly affects the value of the company. Amer et al. (2014) found that audit committee members with an accounting and finance background have a positive effect on a firm's value.

H4: Audit committee effectiveness significantly affects a firm's value

\section{RESEARCH METHODS}

The analysis in this study used multiple linear regressions, with the following model:

$$
Q_{i}=b_{0}+b_{1} K I+b_{2} K M+b_{3} E D E K O M+b_{4} E K A+b_{5} \ln M A+b_{6} \ln T A+\varepsilon_{i}
$$

Qi is the Tobin's $Q$ for the firm's value. Tobin's $Q$ is calculated by (ME+D)/TA; where ME is the number of ordinary shares outstanding multiplied by the closing share price. $\mathrm{D}$ is calculated as total liabilities + inventories - current assets. TA is the book value of total assets. $\mathrm{KI}$ is the institutional ownership, calculated as the percentage of total shares outstanding. $\mathrm{KM}$ is the managerial ownership, calculated as the percentage of total shares outstanding. EDEKOM was measured using a checklist developed by Hermawan (2009). This checklist measures board independence, activities, size, expertise and competence. Table 1 provides the detailed questions in the checklist. EKA is audit committee effectiveness, calculated as the

Table 1. List of questions.

\begin{tabular}{|c|c|}
\hline & Question item \\
\hline Board independence & $\begin{array}{l}\text { The percentage of independent commissioners on the Board of Commissioners } \\
\text { The chairman of the Board of Commissioners is an independent commissioner } \\
\text { There is a clear definition of independent commissioner in the annual report } \\
\text { The percentage of commissioners working for shareholders or any affiliation } \\
\text { Company has a nomination and remuneration committee } \\
\text { The average assignment period for the Board of Commissioners }\end{array}$ \\
\hline Board activities & $\begin{array}{l}\text { There is a clear statement of the job descriptions for the Board of Commissioners } \\
\text { The number of meetings of the Board of Commissioners in a year } \\
\text { The average attendance of the Board of Commissioners in a year } \\
\text { The Board of Commissioners evaluate the financial statement } \\
\text { The Board of Commissioners evaluate the annual management performance } \\
\text { The Board of Commissioners evaluate business projects proposed by } \\
\text { management }\end{array}$ \\
\hline Board size & The number of people on the Board of Commissioners \\
\hline $\begin{array}{l}\text { board expertise and } \\
\text { competence }\end{array}$ & $\begin{array}{l}\text { The percentage of commissioners having a finance and accounting background } \\
\text { The percentage of commissioners having business and managerial experience } \\
\text { The percentage of commissioners having an understanding of the company's } \\
\text { business process } \\
\text { The average age of the Board of Commissioners }\end{array}$ \\
\hline
\end{tabular}


percentage of audit committee members with accounting and financial backgrounds. LnMA is the natural logarithm of the number of audit committee meetings in one year. LnTA is the natural logarithm of total assets. The samples used in this study were the companies listed in the Indonesia Stock Exchange in 2014, other than those from the financial sector.

\section{EMPIRICAL RESULTS}

The final samples were 412 companies. Table 2 shows the descriptive statistics, and Table 3 shows the correlations among variables.

Table 3 shows that there was only a significant correlation with the dependent variable with the control variable of LnTA and that other independent variables did not have a significant correlation with a firm's value. There was no potential multicollinearity expected from the data. Table 4 provides the regression results.

Table 2. Descriptive statistics.

\begin{tabular}{lccccl}
\hline Variable & Mean & Median & Maximum & Minimum & Std. Dev. \\
\hline Q & 1.20 & 0.88 & 7.94 & -9.76 & 1.28 \\
KI & 0.64 & 0.67 & 0.99 & 0.00 & 0.24 \\
KM & 0.05 & 0.00 & 0.85 & 0.00 & 0.13 \\
EDEKOM & 41.15 & 42.00 & 51.00 & 0.00 & 5.43 \\
EKA & 0.58 & 0.67 & 1.00 & 0.17 & 0.23 \\
MA & 5.9 & 4.00 & 45.00 & 1.00 & 5.28 \\
TA & $6,948,670$ & $2,079,180$ & $85,938,885$ & 7,000 & $12,846,942$ \\
\hline
\end{tabular}

Table 3. Correlation results.

\begin{tabular}{lrcrrrrr}
\hline Variable & Q & KI & KM & EDEKOM & EKA & LnMA & LnTA \\
\hline Q & 1.000000 & & & & & & \\
KI & -0.026076 & 1.000000 & & & & & \\
KM & 0.004404 & $-0.368381^{*}$ & 1.000000 & & & & \\
EDEKOM & 0.095547 & 0.038488 & -0.166319 & 1.000000 & & & \\
EKA & -0.018634 & 0.078317 & -0.028510 & -0.009367 & 1.000000 & & \\
LnMA & -0.033221 & -0.088078 & -0.007276 & 0.040863 & 0.018918 & 1.000000 & \\
LnTA & $0.286686^{*}$ & $-0.125177^{*}$ & 0.056815 & 0.080965 & -0.101541 & -0.017966 & 1.000000 \\
\hline
\end{tabular}

*significant at $5 \%$.

Table 4. Regression results.

\begin{tabular}{lccc}
\hline Variable & Coefficient & t-Statistic & Prob. \\
\hline C & -0.355337 & -1.011657 & 0.3123 \\
KI & 0.018956 & 0.069609 & 0.9445 \\
KM & 0.021282 & 0.044672 & 0.9644 \\
EDEKOM & 0.190604 & 1.512809 & 0.1312 \\
EKA & 0.061643 & 0.240807 & 0.8098 \\
LnMA & -0.053791 & -0.917916 & 0.3592 \\
LnTA & $0.112324 * * *$ & 8.317736 & 0.0000 \\
& R-squared & 0.088564 & \\
& Adjusted R-squared & 0.074248 & \\
& F-statistic & 6.186441 & \\
& Prob(F-statistic) & $0.000003^{* * *}$ & \\
\hline
\end{tabular}




\section{DISCUSSION}

\subsection{Ownership structure and firm value}

The regression analysis did not provide any evidence of a relationship between institutional ownership and a firm's value. This result is consistent with Rusiti and Welim (2014), who stated that institutional share ownership does not affect a firm's value. The regression analysis also did not provide any evidence of a relationship between managerial ownership and a firm's value. Indonesian stock market is still considered as having a weak form market efficiency, so the flow of information towards those undertaking transactions in the market is still not in the best condition. The rise and flow of stock prices are still affected by the reputation of the company; the ownership structure is not a factor in determining the price. The market only focuses on the results and performance of the company, which therefore means that control by an institution or by the management is an insignificant factor in affecting a firm's value.

\subsection{Board of commissioners' and audit committee effectiveness and firm value}

The regression analysis did not provide any evidence of a relationship between the effectiveness of the board of commissioners and a firm's value. The regression analysis also did not provide any evidence of a relationship between the audit committee and a firm's value. This shows that neither the monitoring by the board of commissioners nor the help of the audit committee is very effective in affecting the performance of the company. This is probably due to the fact that most of the companies listed in the study samples appointed only one accounting expert to meet the regulatory requirements, namely 'one independent director should be the accounting expert on the audit committee'. Moreover, the audit committee member is usually derived from academic institutions and lacks experience in the industry.

\section{CONCLUSION}

The regression results show that only the variable of total asset that has a relationship with firm's value. All other variables do not have empirical support to having any impact to firm value. The hypothesis stating that a firm's value is affected by the ownership structure and corporate governance mechanism is not proven by the 2014 data in Indonesia. This shows that the model itself should be tested for further research.

\section{REFERENCES}

Abukosim, M., Ferina, I.S. \& Nurcahaya, C. (2014). Ownership structure and firm values: Empirical study on Indonesia manufacturing listed companies. International Refereed Research Journal, $5(4), 41$.

Afza, T. \& Nazir, M.S. (2014). Audit quality and firm value: A case of Pakistan. Research Journal of Applied Sciences, Engineering and Technology, 7(9), 1803-1810. http://maxwellsci.com/print/rjaset/ v7-1803-1810.pdf.

Al-Najjar, B. (2012). The determinants of board meetings: Evidence from categorical analysis. Journal of Applied Accounting Research, 13(2), 178-190. http://dx.doi.org/10.1108/09675421211254867.

Amba, S.M. (2014). Corporate governance and firm's financial performance. Journal of Academic and Business Ethics, Vol. 8.

Amer, M., Ragap, A.A. \& Shehata, S.E. (2014). Audit committee characteristics and firm performance: Evidence from Egyptian listed companies. Paper presented at the Proceedings of 6th Annual American Business Research Conference, Sheraton LaGuardia East Hotel, New York, USA, June 9-1-, 2014. http://wbiworldconpro.com/uploads/new-york-conference-2014/accounting/1401859517_116Mrwan.pdf.

Azharia, A. (2007). The effect of institutional ownership, managerial ownership, sales, and age to firm value. (Unpublished thesis). Universitas Indonesia. 
Barnhart, S.W. \& Rosenstein, S. (1998). Board composition, managerial ownership, and firm performance: An empirical analysis. The Financial Review, 33(303), 1-16. doi:10.1111/j.1540-6288.1998. tb01393.x.

Bonn, I. (2004). Board structure and firm performance: Evidence from Australia. Journal of Management and Organization,10(1), 14-24. doi:10.5172/jmo.2004.10.1.14.

Brigham, E.F. \& Houston, J.F. (2006). Fundamentals of financial management (10thed., translated version). Jakarta: Salemba Empat.

Daniri, M.A. \& Simatupang, A.I. (2009). Internal audit transformation to create good corporate governance. National Committee for Governance Policy. 1-3. http://www.kadin-indonesia.or.id/enm/ images/dokumen/KADIN-167-3751-15042009.pdf.

Darmawati, D. (2004). The relation of corporate governance and firm performance. Paper presented at Simposium Nasional Akuntansi VII, Denpasar, December 2-3, 2004.

Debby, J.F., Mukhtaruddin, Yuniarti, E., Saputra, D.\& Abukosim. (2014). Good corporate governance's characteristics and firm's value: Empirical study of listed banking on Indonesia Stock Exchange. GSTF Journal on Business Review (GBR), 3(4), 81-88. doi: 10.5176/2010-4804_3.4.346.

Fauzi, F. \& Locke, S. (2012). Board structure, ownership structure and firm performance: A study of New Zealand listed-firms. Asian Academy of Management Journal of Accounting and Finance, 8(2), 43-67.

Finance Ministry of the Republic of Indonesia. (2012). Decree No: KEP-643/BL/2012 on the Creation and Operational Guidance of Audit Committee.

Ghozali, I. (2005). The application of multivariate analysis using SPSS. Semarang: Badan Penerbit Universitas Diponegoro.

Giri, M.I.A. (2008). The effect of independent commissioner, managerial ownership, institutional ownership, and concentrated ownership to performance and firm value in Indonesia Stock Exchange. (Unpublished Thesis). Universitas Indonesia.

Haruman, T. (2008). Ownership structure, financial decision, and firm value. Paper presented at Simposium Nasional Akuntansi XI, University of Tanjungpura, Pontianak, Juli 23-26, 2008.

Hasibuan, M.S.P. (2002). Human Resource Management. Jakarta: BumiAksara.

Herawati, V. (2008). The role of corporate governance practices as a moderating variable to the effect of earning management to firm value. Paper presented at Simposium Nasional Akuntansi XI, University of Tanjungpura, Pontianak, Juli 23-26, 2008.

Hermawan, A.A. (2009). The effect of board of commissioners' and audit committee's effectiveness, family ownership, and bank monitoring role to earnings information content. (Unpublished doctoral thesis). Universitas Indonesia.

Isshaq, Z., Bokpin, G.A. \& Onumah, J.M. (2009). Corporate governance, ownership structure, cash holdings and firm value on the Ghana Stock Exchange. The Journal of Risk Finance, 10(5), 448-499. http://dx.doi.org/10.1108/15265940911001394.

Jensen, M.C. \& Meckling, W.H. (1976). Theory of the firm: Managerial behaviour, agency costs and ownership structure. Journal of Financial Economics, 3(4), 305-60. doi:10.1016/0304-405X(76)90026-X.

Kumar, J. (2004). Agency theory and firm value in India. Goregaon (East), Mumbai: Indira Gandhi Institute of Development Research. http://unpan1.un.org/intradoc/groups/public/documents/APCITY/UNPAN023822.pdf.

Lastanti, H.S. (2004). The Relation of Corporate Govenance Structure with Firm Performacne and Market Reaction. Paper Presented at National Conference of Accounting: Accountant Role in Building Good Corporate Governance.

Li, J., Pike, R. \& Haniffa, R. (2008). Intellectual capital disclosure and corporate governance structure in UK firms. Accounting and Business Research, 38(2), 137-59. doi:10.1080/00014788.2008.9663326.

McMullen, D. (1996). Audit committee performance: An investigation of the consequences associated with audit committees. Auditing: A Journal of Practice and Theory, 15 (1), 87-103.

Nurlela, R. \& Islahuddin. (2008). The effect of corporate social responsibility to firm value using managerialownership as moderating variabel. Paper presented at Simposium Nasional Akuntansi XI, University of Tanjungpura, Pontianak, Juli 23-26, 2008.

Ojucari, O. (2012). Corporate governance: The relationship between audit committees and firm values. The Department of Management Sciences, Kwara State University, Malete.

Otoritas, J.K. (2014). Peraturan Otoritas Jasa Keuangan No: 33/POJK.04/2014 on Directors and Board of Commissioners of Publicly Listed Companies. Jakarta: Sekretariat Negara.

Rachmawati, A. \& Triatmoko, H. (2007). Analysis on the factors affecting earnings quality and firm value. Paper presented at Simposium Nasional Akuntansi X, Unhas Makassar, Juli 26-28, 2007. 
Rusiti \& Welim, M.A. (2014). The effect of managerial ownership and institutional ownership to firm value (Empirical study on listed banks in Indonesia Stock Exchange). Unpublished Tesis. Universitas Atmajaya.

Rustiarini, N.W. (2006). The effect of stock ownership structure on the disclosureof corporate social responsibility. Paper presented at Simposium Nasional Akuntansi 9, Padang, August 23-26, 2006.

Sartono, A. (2001). Theories and Application of Financial Management. Yogyakarta BPFE.

Siallagan, H. \& Machfoedz, M. (2006). Corporate governance mechanism, earnings quality, and firm value. Paper presented at Simposium Nasional Akuntansi 9, Padang, August 23-26, 2006.

Sudana, I.M. (2001). Corporate Financial Management. Jakarta: Erlangga.

Sudiyatno, B. \& Puspitasari, E. (2010). Tobin's Q and Altman Z-Score as indicators of company performance measurement. JurnalImiahKajianAkutansi, 2(1), 9-21.

Sugiarto. (2009). Capital structure, firms ownership structure, agency problem, and information asymmetry. Yogyakarta: GrahaIlmu.

Sugiyono.(2009). Quantitative and Qualitative Research Methods. Bandung: CV. Alfabeta.

Sukamulja, S. (2004). Good corporate governance in finance sector: The impact of GCG to firms performance (A case at the Jakarta Stock Exchange).BENEFIT JurnalManajemendanBisnis. http:// journals.ums.ac.id/index.php/benefit/article/view/1193.

Swastika, S. (2013). The effect ownership structure and good corporate governance practice on thevalue of non financial companies listed in Indonesia Stock Exchangeduring 2006-2011. (Unpublished thesis). Universitas Gajah Mada.

Tarjo. (2008). The effect of institutional ownership concentration and leverage to earnings management, stockholders values, and cost of equity capital. Paper presented at Simposium Nasional Akuntansi 9, Padang, August 23-26, 2006.

Vafeas, N. (1999). Board meeting frequency and firm performance. Journal of Financial Economics, 53(1), 113-42. doi:10.1016/S0304-405X(99)00018-5.

Vintilă, G. \& Gherghina, S.C. (2015). Does ownership structure influence firm value? An empirical research towards the Bucharest Stock Exchange listed companies. International Journal of Economics and Financial Issues, 5(2), 501-14. doi:10.1016/S2212-5671(14)00500-0.

Wahyudi, U. \& Pawestri, H.P. (2006). The implication of ownership structure to firm value with financial decisions as intervening variable. Paper presented at Simposium Nasional Akuntansi 9, Padang, August 23-26, 2006.

Yin, F., Gao, S.,Li, W. \& Lv, H. (2012). Determinants of audit committee meeting frequency: Evidence from Chinese listed companies. Managerial Auditing Journal, 27(4), 425-444. http://dx.doi. org/10.1108/02686901211218003. 